\title{
The influence of surface improvement of mountain riparian meadows of the Carpathians Mountains on their productivity and the quality of food
}

\author{
Kyrhak V. ${ }^{1}$, Voloshchuk M. ${ }^{2}$, Karbivska Yu. ${ }^{3}$, Martyshchuk V. ${ }^{4}$ \\ ${ }^{1} \mathrm{NSC}$ «Institute of Agriculture of NAAS» \\ 2b Mashynobudivnykiv Str., Chabany, Kyievo-Sviatoshynskyi district, Kyiv oblast, Ukraine, 08162 \\ $2-4$ Vasyl Stefanyk Precarpathian National University \\ 57 Shevchenko Str., Ivano-Frankivsk, Ukraine, 76018 \\ e-mail: ${ }^{1}$ kurgak_luki@ukr.net, ${ }^{3}$ yljakarbivska@ukr.net \\ ORDIC: ${ }^{10000-0003-2309-0128,{ }^{3} 0000-0002-0540-8887}$
}

Goal. To determine the features of the formation of efficiency, chemical composition, nutritive value, and energy content of grass forages depending on surface improvement of meadows of the mountain-forest belt of the Carpathians Mountains. Methods. Field, laboratory, mathematical-statistical. Results. It is shown that productivity of dry matter for 1 ha over 3 years of research made on average: for haymaking $-2.15-4.77 \mathrm{t}$, for perennial mowing - $1.95-4.11 \mathrm{t}$. For haymaking usage, the highest productivity was at sowing the mixtures of cereal grasses on the background of N60P30K60. For perennial mowing usage, the highest productivity was at sowing white clover on the background of P30K60. It respectively made $12 \%$ and $85 \%$ more than in the variants without interplanting, and $122 \%$ and $111 \%$ more than in the variants without surface improvement. The best uniformity of distribution of crop biomass was obtained for perennial mowing with interplanting white clover on the background of P30K60. In this case, the share of the 1st mowing was 39\%, 2nd - 33, and 3rd - 28\% with the unevenness expressed by the coefficient of variation of $18 \%$. From measures of surface improvement of forage quality as to chemical composition (a primarily, increase of the content of crude protein) they noted the introduction of N60P30K60 or $15 \mathrm{t} / \mathrm{ha}$ of manure. For perennial mowing, a similar effect was noted for interplanting white clover on the background P30K60. Regardless of the measures of surface improvement the highest content of crude protein, the best energy content, and the nutritional value of grass fodder had perennial mowing (simulation of pasture meadow). Conclusions. For surface improvement of meadows of the mountain-forest belt of the Carpathians Mountains with natural herbage, the working factors influencing the productivity and improving the quality of grass fodder are the annual introduction of N60P30K60 or $15 \mathrm{t} / \mathrm{ha}$ of manure, or N60P30K60 + interplanting of mixtures of grasses of fescue and timothy for haymaking use, or P30K60 + interplanting of white clover for perennial mowing use. The application of mineral fertilizers in combination with the interplanting of perennial grasses ensures the best positive effect.

Key words: protein, energy, feed units, plantation of grasses, nutrition, natural grass stand, fertilizer. DOI: https://doi.org/10.31073/agrovisnyk202006-03

Today, livestock in Ukraine is insufficiently provided with high-quality high-protein feeds, which is primarily due to low yields of forage crops and their imbalance in protein. Due to the imbalance of feed and a significant deficit of protein in the diet of animals, overconsumption of feed reaches $35 \%$, and the cost of production increases by 1.3-1.5 times. The supply of feed unit with digestible protein is often only $80-85 \mathrm{~g}$ instead of the scientifically substantiated 105-115 g [1].

Analysis of recent research and publications. Hayfields and pastures are a source of high quality and cheap fodder for livestock. Hay remains one of the main feeds in the diets of animals, as it promotes the normal functioning of the stomach and intestines. It is the only roughage that contains vitamin $D$, which regulates mineral metabolism in animals [2].

To increase the productivity of natural fodder lands and provide livestock with high-quality fodder, measures of their surface improvement are widely carried out. Scientific research and production experience show that with a relatively small investment of material and financial resources, the production of fodder on pastures and meadows can be doubled. Improving natural grasslands by applying fertilizers makes it possible to form highly productive, with improved feed quality and long-term use of agrocenosis [3-6].

World experience convincingly proves that the second most important factor for agricultural production is fertilizers. The introduction of scientifically sound standards of mineral and organic fertilizers can ensure a deficit-free balance of nutrients and humus [7].

In addition to increasing yields, onion growers face no less important task - obtaining high quality feed. One of the main criteria for assessing the nutritional value of feed is the content of digestible protein, the lack of which in the diet reduces the productive effect of other nutrients [8].

The content of organic and mineral substances that reflect the nutritional value of feed depends on the phenological phase of growth and development of plants. Perennial herbs are most nutritious in the early stages of the growing season, because during this period they contain not only complete protein, vitamins, but in small quantities and more acceptable to animals fiber, where there is little lignin, so it is well digested [9]. 
Types of meadow phytocenosis grasses have an important influence on the quality of fodder, therefore the selection of grasses for creation of new agrophytocenoses plays a crucial role in ensuring high quality. Herbaceous plants, which include more leafy lower grasses or upper grasses with surface foliage, contain 19 - 38\% more leaves, are better supplied with nutrients and have higher energy saturation. Unequal content of nutrients was found in some plant organs $[10,11]$.

In recent years, work on surface improvement of pastures has virtually stopped. But there are significant reserves that can increase the productivity of grasslands by 1.5-2.0 times, as well as improve feed quality. No matter how extreme the soil and climatic conditions of the Carpathian region, there are reserves for increasing farm productivity. Thus, the content of $50 \%$ of creeping clover in the grass mixture completely solves the protein problem, and $20 \%$ of carbohydrates in fenugreek fenugreek (instead of $8 \%$ in the prey) replace expensive carbohydrate feeds (corn, beets, molasses and partially concentrates) [12]. Studies by foreign and domestic scientists have shown that the use of various methods of surface improvement of old meadows (systematic fertilization with mineral fertilizers, rejuvenation of grass by disking turf) productivity of pasture grasslands increases by an average of 2.2-2.5 times or 6 to $5.6-6.5$ t/ha of dry mass. Sowing of perennial legumes in turf provides an increase in the share of legume components in the crop to 43 and $47 \%$ and an increase in productivity by $1.5-1.8$ times [13,11].

Mineral fertilizer has a significant effect on feed quality. Researchers at the University of Nevada (USA) report a positive effect of moderate doses of nitrogen fertilizers applied to meadow grass for long-term use (1946-1987) on feed quality, providing an increase in crude protein content in the dry weight of feed by $2.6 \%$ compared to control unfertilized variant [14]. Studies conducted in Canada show that the application of nitrogen fertilizers does not affect the content of crude protein in legumes, and increases its content in cereals in the first mowing [15].

The purpose of research. Establish the peculiarities of the formation of productivity, as well as the chemical composition, nutritional value and energy consumption of grass fodder depending on the measures of surface improvement of meadows of the mountain-forest belt of the Carpathians.

Materials and methods of research. Experimental studies to study the measures of surface improvement of floodplain meadows of the Carpathian mountain-forest belt with natural grass cover under different modes of use were performed during 2017-2019 on sod-brown soil (shallow) soils in the farm of Martyschuk VF (Krasnyk village, Verkhovyna district, Ivano-Frankivsk region). The size of sown areas $-10 \mathrm{~m}^{2}$, accounting $-8 \mathrm{~m}^{2}$. The experiment was repeated four times. Number of options -14 , plots -56 . Mineral fertilizers in all doses were applied in the spring at the same time. The scheme of the experiment included the following options and factors: Factor $A$ - (improvement): no improvement, $\mathrm{P}_{30} \mathrm{~K}_{60}, \mathrm{~N}_{60} \mathrm{P}_{30} \mathrm{~K}_{60}, 15 \mathrm{t} / \mathrm{ha}$ of manure, P30K60 + sowing of creeping clover $6 \mathrm{~kg} / \mathrm{ha}$ for multi-use and $\mathrm{N} \mathrm{OP}_{30} \mathrm{~K}_{60}+$ sowing of a mixture of cereals (timothy, meadow $6 \mathrm{~kg} / \mathrm{ha}+$ meadow fire, $10 \mathrm{~kg} / \mathrm{ha}$ ). Factor B - mode of use: haymaking with 2 slopes and multimowing (imitation of pasture use).

The research was performed according to the methodology of the Institute of Feed NAAS [16]. Dry matter content (dry mass) - thermostatic-weight method at a temperature of $105^{\circ} \mathrm{C}$. The chemical composition of the feed was determined in plant samples taken during harvest, air-dried and ground. The dry matter of vegetable mass was determined by the content of crude protein, protein, crude fat, crude fiber and digestibility of dry matter in vitro - by infrared spectroscopy, the content of nitrogen-free extractives (NER) - by calculation. The content of feed units, gross and metabolic energy in feed was determined by a calculation method using the coefficients of digestibility of dry matter of feed and the content of crude protein, crude fat, crude fiber, BER [17]. Mathematical processing of research results was performed by methods of analysis of variance and variation statistics according to Dospekhov B.A. [18].

Research results. The results of our research to study the impact of measures to improve surface floodplain meadows with natural grassland of the Black Cheremosh River mountain-forest belt of the Carpathians showed that the original grassland before the experiment was grass-grass with a content of wild cereals $53-54 \%$, grass - $39-42 \%$ and unsown legumes $4-8 \%$.

Analysis of the productivity of floodplain meadows with natural grassland depending on surface improvement measures showed that it averaged over the years of research on the yield of 1 ha of dry mass of hay use ranged from 2.15 to 4.77 tons, and multi-crop -1.95 to $4,11 \mathrm{t}$ (Table 1 ).

Thus, productivity was $10-16 \%$ higher for haymaking than for multi-mowing use. While the yield of 1 ha of feed units and crude protein had a certain advantage (by 5-6\%) in all variants had a multi-slope mode of use.

In the haymaking mode, the highest productivity was for sowing a mixture of cereals on the background of $\mathrm{N}_{60} \mathrm{P}_{30} \mathrm{~K}_{60}$, and in the case of multi-sowing - sowing of creeping clover on the background of $\mathrm{P}_{30} \mathrm{~K}_{60}$, which is 12 and $85 \%$ more compared to non-sowing and 122 and $111 \%$ - compared to option without fertilizer. Additional application of $\mathrm{N}_{60}$ on the background of $\mathrm{P}_{30} \mathrm{~K}_{60}$ in both modes of use increased productivity by yield from 1 ha of dry mass by $70 \%$, and in comparison with the option without application of fertilizers - by $94-95 \%$. Application of manure at a dose of $15 \mathrm{t} / \mathrm{ha}$ increased it from 2.15 to $3.92 \mathrm{t} / \mathrm{ha}$ for haymaking and from 1.95 to $3.52 \mathrm{t} / \mathrm{ha}$ for multi-mowing, which is $7 \%$ less than the application of $\mathrm{N}_{60} \mathrm{P}_{30} \mathrm{~K}_{60}$ and by $24 \%$ compared to variant $\mathrm{N}_{60} \mathrm{P}_{30} \mathrm{~K}_{60}+$ sowing of cereals for haymaking and $17 \%$ compared to variant $\mathrm{P}_{30} \mathrm{~K}_{60}+$ sowing of creeping clover. 
1. Productivity of floodplain meadows depending on the options of surface improvement, $t /$ ha (2017-2019)

\begin{tabular}{|c|c|c|c|c|c|c|c|}
\hline \multirow[b]{2}{*}{$\begin{array}{l}\text { Options for surface } \\
\text { improvement }\end{array}$} & \multicolumn{3}{|c|}{$\begin{array}{c}\text { Dry weight by years of } \\
\text { use }\end{array}$} & \multicolumn{4}{|c|}{ Average for 2017-2019 } \\
\hline & $\begin{array}{l}201 \\
7\end{array}$ & 2018 & 2019 & 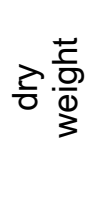 & 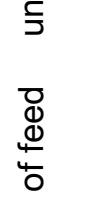 & 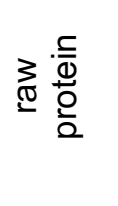 & 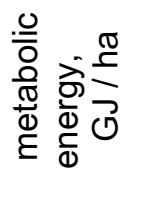 \\
\hline \multicolumn{8}{|c|}{ Haymaking use } \\
\hline Without improvement & $60^{1}$ & $\begin{array}{l}2,3 \\
0\end{array}$ & $\begin{array}{l}2,5 \\
5\end{array}$ & $\begin{array}{l}2,1 \\
5\end{array}$ & $6^{1,4}$ & 0,25 & 19,4 \\
\hline $\mathrm{P}_{30} \mathrm{~K}_{60}$ & $92^{1}$ & $\begin{array}{l}2,6 \\
2\end{array}$ & 2,8 & $\begin{array}{l}2,4 \\
7\end{array}$ & $\begin{array}{l}1,7 \\
0\end{array}$ & 0,30 & 22,2 \\
\hline $\mathrm{N}_{60} \mathrm{P}_{30} \mathrm{~K}_{60}$ & $\begin{array}{l}3, \\
65\end{array}$ & $\begin{array}{l}4,3 \\
2\end{array}$ & $\begin{array}{l}4,6 \\
3\end{array}$ & $\begin{array}{l}4,2 \\
0\end{array}$ & $\begin{array}{l}2,9 \\
4\end{array}$ & 0,60 & 38,2 \\
\hline $\begin{array}{l}\mathrm{N}_{60} \mathrm{P}_{30} \mathrm{~K}_{60}+\text { sowing of } \\
\text { cereals }\end{array}$ & $\begin{array}{r}4, \\
22\end{array}$ & \begin{tabular}{|l|}
4,9 \\
4
\end{tabular} & $\begin{array}{l}5,1 \\
5\end{array}$ & $\begin{array}{l}4,7 \\
7\end{array}$ & $\begin{array}{l}3,3 \\
4\end{array}$ & 0,69 & 43,9 \\
\hline Manure, 15 T/ha & 3 & $\begin{array}{l}4,0 \\
3\end{array}$ & $\begin{array}{l}4,3 \\
6\end{array}$ & $\begin{array}{l}3,9 \\
2\end{array}$ & $\begin{array}{l}2,7 \\
0\end{array}$ & 0,55 & 35,7 \\
\hline $\mathrm{HIP}_{05}, \mathrm{~T} / \mathrm{ha}$ & $\begin{array}{c}0 \\
15 \\
\end{array}$ & $\begin{array}{l}0,1 \\
6\end{array}$ & 0,1 & $\begin{array}{l}0,1 \\
6\end{array}$ & & & \\
\hline \multicolumn{8}{|c|}{ Multi-use } \\
\hline Without improvement & $\begin{array}{l}1 \\
40\end{array}$ & $\begin{array}{l}2,1 \\
0\end{array}$ & $\begin{array}{l}2,3 \\
5\end{array}$ & $\begin{array}{l}1,9 \\
5\end{array}$ & $\begin{array}{l}1,5 \\
4\end{array}$ & 0,29 & 19,1 \\
\hline $\mathrm{P}_{30} \mathrm{~K}_{60}$ & $\begin{array}{l}1 \\
65\end{array}$ & $\begin{array}{l}2,3 \\
3\end{array}$ & $\begin{array}{l}2,6 \\
6\end{array}$ & 2,2 & $8^{1,7}$ & 0,34 & 21,8 \\
\hline $\begin{array}{l}\mathrm{P}_{30} \mathrm{~K}_{60}+\text { creeping clover } \\
\text { sowing }\end{array}$ & $\begin{array}{l}3 \\
56\end{array}$ & $\begin{array}{l}4,2 \\
2\end{array}$ & $\begin{array}{l}4,5 \\
5\end{array}$ & $\begin{array}{l}4,1 \\
1\end{array}$ & $\begin{array}{l}3,4 \\
1\end{array}$ & 0,79 & 41,1 \\
\hline $\mathrm{N}_{60} \mathrm{P}_{30} \mathrm{~K}_{60}$ & 33 & $\begin{array}{l}3,9 \\
3\end{array}$ & $\begin{array}{l}4,1 \\
8\end{array}$ & $\begin{array}{l}3,7 \\
8\end{array}$ & $\begin{array}{l}3,0 \\
6\end{array}$ & 0,69 & 37,0 \\
\hline Manure, 15 T/ha & $\begin{array}{r}2, \\
97\end{array}$ & $\begin{array}{l}3,7 \\
2^{3,7}\end{array}$ & $\begin{array}{l}3,8 \\
7\end{array}$ & $2^{3,5}$ & $\begin{array}{l}2,8 \\
5\end{array}$ & 0,63 & 34,5 \\
\hline $\mathrm{HIP}_{05}, \mathrm{~T} / \mathrm{ha}$ & 13 & $\begin{array}{l}0,1 \\
5\end{array}$ & $\begin{array}{l}0,1 \\
6\end{array}$ & $\begin{array}{l}0,1 \\
6\end{array}$ & & & \\
\hline
\end{tabular}

Regularities of productivity at the rate of 1 ha of dry mass, depending on the studied options for surface improvement and modes of use, which were on average for 2017-2019, have been preserved over the years of research.

The highest productivity gains in all slopes were for haymaking in the case of sowing a mixture of cereals on the background of $\mathrm{N}_{60} \mathrm{P}_{30} \mathrm{~K}_{60}$, and for multi-mowing - creeping clover on the background of $\mathrm{P}_{30} \mathrm{~K}_{60}$, and the smallest in the version without fertilizer for both modes of use (Table 2).

2. Distribution of the dry mass yield of floodplain meadows depending on the options for surface improvement (average for 2017-2019)

\begin{tabular}{|c|c|c|c|c|c|c|c|}
\hline \multirow{3}{*}{$\begin{array}{l}\text { Options for surface } \\
\text { improvement }\end{array}$} & \multicolumn{3}{|c|}{ T/ha } & \multicolumn{3}{|c|}{$\%$} & \multirow{3}{*}{$\underset{\% *}{V,}$} \\
\hline & \multicolumn{6}{|c|}{ Slopes } & \\
\hline & 1st & 2nd & $3 r d$ & 1st & 2nd & $3 r d$ & \\
\hline \multicolumn{8}{|c|}{ Haymaking use } \\
\hline Without improvement & 1,46 & 0,69 & - & 68 & 32 & - & - \\
\hline $\mathrm{P}_{30} \mathrm{~K}_{60}$ & 1,63 & 0,84 & $\begin{array}{cc}- \\
\end{array}$ & 66 & 34 & - & - \\
\hline $\mathrm{N}_{60} \mathrm{P}_{30} \mathrm{~K}_{60}$ & 2,48 & 1,72 & - & 59 & 41 & - & - \\
\hline $\begin{array}{l}\mathrm{N}_{60} \mathrm{P}_{30} \mathrm{~K}_{60}+\text { sowing of } \\
\text { cereals }\end{array}$ & 2,77 & 2,00 & - & 58 & 42 & - & - \\
\hline Manure, 15 T/ha & 2,23 & 1,69 & 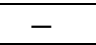 & 57 & 43 & 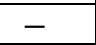 & - \\
\hline $\mathrm{HIP}_{05}, \mathrm{~T} / \mathrm{ha}$ & 0,14 & 0,09 & & & & & \\
\hline \multicolumn{8}{|c|}{ Multi-use } \\
\hline Without improvement & 0,96 & 0,62 & 0,37 & 49 & 32 & 19 & 42 \\
\hline $\mathrm{P}_{30} \mathrm{~K}_{60}$ & 1,03 & 0,75 & 0,44 & 46 & 34 & 20 & 39 \\
\hline $\begin{array}{l}P_{30} K_{60}+\text { creeping clover } \\
\text { sowing }\end{array}$ & 1,60 & 1,36 & 1,15 & 39 & 33 & 28 & 18 \\
\hline $\mathrm{N}_{60} \mathrm{P}_{30} \mathrm{~K}_{60}$ & 1,59 & 1,25 & 0,94 & 42 & 33 & 25 & 25 \\
\hline Manure, 15 T/ha & 1,48 & 1,23 & 0,81 & 42 & 35 & 23 & 27 \\
\hline $\mathrm{HIP}_{05}, \mathrm{~T} / \mathrm{ha}$ & 0,08 & 0,06 & 0,04 & & & & \\
\hline
\end{tabular}


During haymaking, two slopes were obtained with productivity parameters in the 1st slope of 1.46-2.77 tons and in the 2 nd $-0.69-2.00$ tons with a share of the total yield of $58-68 \%$ and $32-43 \%$. Significantly uniform distribution of the crop on the slopes was in the variants with the introduction of $\mathrm{N}_{60} \mathrm{P}_{30} \mathrm{~K}_{60}, \mathrm{~N}_{60} \mathrm{P}_{30} \mathrm{~K}_{60}+$ sowing of cereals and the addition of $15 \mathrm{t} / \mathrm{ha}$ of manure, with a smaller share of the 1 st mowing $(57-59 \%)$ and a larger 2nd (41-43\%), in comparison with the variants without fertilizers and with the application of $\mathrm{P}_{30} \mathrm{~K}_{60}$, where the share of the 1st slope was higher (66-68\%) and the 2nd - lower (32-34\%).

With multi-slope use on all variants of surface improvement in comparison with hay use, the distribution of yield by slopes was uniform, when three slopes were obtained with productivity parameters at the yield of 1 ha of dry mass in the 1 st slope $0.96-1.59 \mathrm{t}, 2 \mathrm{th}-0.62-1.36$ and $3 \mathrm{rd}-0.37-1.15$ tons with a share of the total harvest of $39-49 \%, 32-35 \%$ and $19-25 \%$, respectively.

The most uniform distribution of yield by slopes was in the variants with the introduction of $\mathrm{P}_{30} \mathrm{~K}_{60}+$ creeping clover sowing with a share of 1 st slope $39 \%, 2 \mathrm{nd}-33$ and $3 \mathrm{rd}-28 \%$ and non-uniformity, which is expressed by the coefficient of variation - $18 \%$. Less uniform distribution of the crop on the slopes was in the variants without fertilizers and on the application of $\mathrm{P}_{30} \mathrm{~K}_{60}$ with the share of the 1 st mowing $46-49 \%$, the second - 32$34 \%$ and the $3 \mathrm{rd} 19-20 \%$ and the unevenness $-42 \%$. Variants with the introduction of $\mathrm{N}_{60} \mathrm{P}_{30} \mathrm{~K}_{60}$ or 15 t/ha of manure on the slopes occupied an intermediate position compared to the above options.

Analysis of indicators of organic matter content in feed and its digestibility in floodplain meadows depending on surface improvement measures showed that these indicators were most influenced by the mode of use. The best feed quality was in the multi-use mode (Table 3 ).

With multi-use in comparison with hay in all variants, the content of crude protein in the dry weight increased from $11.9-14.5$ to $15.2-19.2 \%$ and protein - from $10.0-12.2$ to $12.6-15.9$, the content of crude fiber decreased by $3.5-4.2 \%$ and nitrogen-free extractives by $1.5-1.7 \%$. At the same time, the digestibility of dry feed in vitro increased from $61-62$ to $70-72 \%$.

Among the options for surface improvement of the experiment with hay use, the most positive effect on the chemical composition of the feed had options with the introduction of $\mathrm{N}_{60} \mathrm{P}_{30} \mathrm{~K}_{60}, \mathrm{~N}_{60} \mathrm{P}_{30} \mathrm{~K}_{60}+$ sowing of cereals and with the introduction of $15 \mathrm{t} / \mathrm{ha}$ of manure. In this case, in comparison with the variants without fertilizers and with the application of $\mathrm{P}_{30} \mathrm{~K}_{60}$, the content of crude protein increased by $2.3 \%$, protein $-1.8-2.0 \%$ and decreased the content of BER by 2.3-3.2\%.

In the case of multi-use, the best indicators of chemical composition were characterized by the variant with the introduction of P30K60 + sowing of creeping clover, where the content of crude protein and protein in the dry mass was the highest (19.2 and $15.9 \%$, respectively), which is $1.0-1.3$ and $0.8-1.0 \%$ more than in the variants with $\mathrm{N}_{60} \mathrm{P}_{30} \mathrm{~K}_{60}$ application by 3.8-4.0 and 3.3-3.1\% with variants without fertilizers and with $\mathrm{P}_{30} \mathrm{~K}_{60}$ application. At the same time, in the variants with application of $\mathrm{N}_{60} \mathrm{P}_{30} \mathrm{~K}_{60}, \mathrm{P}_{30} \mathrm{~K}_{60}+$ sowing of creeping clover and with application of $15 \mathrm{t} / \mathrm{ha}$ of manure in comparison with variants without fertilizers or with application of $\mathrm{P}_{30} \mathrm{~K}_{60}$, the content of $\mathrm{BER}$ was $2.8-3.4 \%$ lower. In the case of multifaceted use, among the options for surface improvement, the highest content of crude fat was characterized by the option with the introduction of $\mathrm{P}_{30} \mathrm{~K}_{60}$ + creeping clover, where its content was $4.2 \%$, which is $0.4 \%$ more than other options.

3. The content of organic matter in the feed and its digestibility in floodplain meadows, depending on the options for surface improvement

\begin{tabular}{|c|c|c|c|c|c|c|}
\hline $\begin{array}{l}\text { Options for surface } \\
\text { improvement }\end{array}$ & $\begin{array}{l}\text { Crude } \\
\text { protein }\end{array}$ & Protein & $\begin{array}{l}\text { Crude } \\
\text { fat }\end{array}$ & $\begin{array}{l}\text { Cheese } \\
\text { fiber }\end{array}$ & BER & Digesti-bility \\
\hline \multicolumn{7}{|c|}{ Haymaking use } \\
\hline Without improvement & 11,9 & 10,0 & 3,6 & 27,7 & $\begin{array}{l}48 \\
2\end{array}$ & 61 \\
\hline $\mathrm{P}_{30} \mathrm{~K}_{60}$ & 12,2 & 10,2 & 3,7 & 27,6 & $\begin{array}{l}47 \\
8\end{array}$ & 62 \\
\hline $\mathrm{N}_{60} \mathrm{P}_{30} \mathrm{~K}_{60}$ & 14,4 & 12,1 & 3,8 & 28,4 & $\begin{array}{l}45 \\
0\end{array}$ & 62 \\
\hline $\begin{array}{l}\mathrm{N}_{60} \mathrm{P}_{30} \mathrm{~K}_{60}+\text { sowing of } \\
\text { cereals }\end{array}$ & 14,5 & 12,2 & 3,8 & 28,8 & $\begin{array}{l}44 \\
6\end{array}$ & 61 \\
\hline Manure, 15 T/ha & 14,2 & 11,8 & 3,7 & 27,7 & $\begin{array}{l}45 \\
9\end{array}$ & 62 \\
\hline $\mathrm{HIP}_{05}, \mathrm{~T} / \mathrm{ha}$ & 0,7 & 0,6 & 0,2 & 1,8 & 2,4 & 3 \\
\hline \multicolumn{7}{|c|}{ Multi-use } \\
\hline Without improvement & 15,2 & 12,6 & 3,8 & 24,8 & $\begin{array}{l}46 \\
5\end{array}$ & 70 \\
\hline $\mathrm{P}_{30} \mathrm{~K}_{60}$ & 15,4 & 12,8 & 3,8 & 24,5 & $\begin{array}{l}46 \\
5\end{array}$ & 71 \\
\hline $\begin{array}{l}P_{30} K_{60}+\text { creeping clover } \\
\text { sowing }\end{array}$ & 19,2 & 15,9 & 4,2 & 23,5 & $\begin{array}{l}43 \\
2\end{array}$ & 72 \\
\hline $\mathrm{N}_{60} \mathrm{P}_{30} \mathrm{~K}_{60}$ & 18,2 & 15,1 & 3,8 & 25,3 & $\begin{array}{l}43 \\
1\end{array}$ & 70 \\
\hline
\end{tabular}




\begin{tabular}{|l|c|c|c|c|c|c|}
\hline Manure, 15 T/ha & 17,9 & 14,9 & 3,8 & 25,0 & 43, & 70 \\
\hline $\mathrm{HIP}_{05} \mathrm{~T} / \mathrm{ha}$ & 0,8 & 0,7 & 0,2 & 1,7 & 2,2 & 3 \\
\hline Zootechnical norm & $14-20$ & - & - & $25-30$ & - & $50-70$ \\
\hline
\end{tabular}

In terms of dry matter content of organic matter and digestibility of dry matter in both hay and multi-crop use, grass feed met the zootechnical standards of cattle feeding. When used for haymaking, the grass mass in terms of crude protein and crude fiber content fully met the requirements of DSTU 4674: 2006 for the production of second-class hay.

The nutritional and energy consumption of the dry mass and the provision of the feed unit with digestible protein by the grass of floodplain meadows, depending on the measures of surface improvement are shown in table 4.

\section{Nutrition and energy consumption of dry mass and provision of fodder unit with digestible protein by grass of floodplain meadows depending on options of surface improvement (average for 2017-2019)}

\begin{tabular}{|c|c|c|c|}
\hline $\begin{array}{l}\text { Surface options } \\
\text { improvement }\end{array}$ & $\begin{array}{l}\text { Content of feed } \\
\text { units, } \%\end{array}$ & $\begin{array}{c}\text { Content of } \\
\text { metabolic energy, MJ } \\
/ \mathrm{kg}\end{array}$ & $\begin{array}{l}\text { Provision of feed. from } \\
\text { digestible protein, } g\end{array}$ \\
\hline \multicolumn{4}{|c|}{ Haymaking use } \\
\hline Without improvement & 68 & 9,0 & 123 \\
\hline $\mathrm{P}_{30} \mathrm{~K}_{60}$ & 69 & 9,0 & 124 \\
\hline $\mathrm{N}_{60} \mathrm{P}_{30} \mathrm{~K}_{60}$ & 70 & 9,1 & 143 \\
\hline $\begin{array}{l}\mathrm{N}_{60} \mathrm{P}_{30} \mathrm{~K}_{60}+\text { sowing of } \\
\text { cereals }\end{array}$ & 70 & 9,2 & 144 \\
\hline Manure, 15 T/ha & 69 & 9,1 & 144 \\
\hline $\mathrm{HIP}_{05}, \mathrm{~T} / \mathrm{ha}$ & & & \\
\hline \multicolumn{4}{|c|}{ Multi-use } \\
\hline Without improvement & 79 & 9,8 & 129 \\
\hline $\mathrm{P}_{30} \mathrm{~K}_{60}$ & 80 & 9,8 & 134 \\
\hline $\begin{array}{l}\mathrm{P}_{30} \mathrm{~K}_{60}+\text { creeping clover } \\
\text { sowing }\end{array}$ & 83 & 10,0 & 161 \\
\hline $\mathrm{N}_{60} \mathrm{P}_{30} \mathrm{~K}_{60}$ & 81 & 9,8 & 156 \\
\hline Manure, $15 \mathrm{~T} / \mathrm{ha}$ & 81 & 9,8 & 154 \\
\hline $\mathrm{HIP}_{05}, \mathrm{~T} / \mathrm{ha}$ & $70-100$ & $8-11$ & $110-115$ \\
\hline
\end{tabular}

It was found that these indicators were most influenced by the mode of use. With multi-crop use on all variants of surface improvement, the content of feed units in the dry weight of feed ranged from 79 to $83 \%$, which is $11-14 \%$ more than with hay use. The content of metabolic energy in the case of multi-mowing use ranged from $9.8-10.0 \mathrm{MJ} / \mathrm{kg}$ of dry weight, which is $0.7-0.9 \mathrm{MJ} / \mathrm{kg}$ more than in the case of haymaking. The supply of fodder protein with digestible protein in the case of multi-use was in the range of $129-161 \mathrm{~g}$, which is $6-18 \mathrm{~g}$ more than in the case of hay use.

No significant difference was observed between the surface improvement options in terms of dry matter content of feed units and metabolic energy for both hay and multi-mowing use. In terms of feed unit content of digestible protein, the variants with application of $\mathrm{N}_{60} \mathrm{P}_{30} \mathrm{~K}_{60}, \mathrm{P}_{30} \mathrm{~K}_{60}+$ sowing of creeping clover and with application of $15 \mathrm{t} /$ ha of manure with indicators of 143-144 $\mathrm{g}$ for hay use and 154-161 $\mathrm{g}$ for multi-crop use, which corresponds to $9-10$ and 20-32 g more in comparison with variants without fertilizers or with application of $\mathrm{P}_{30} \mathrm{~K}_{60}$.

In terms of dry matter content of feed units and metabolic energy for both haymaking and multi-mowing use, grass fodder met the zootechnical standards of cattle feeding, and for providing the fodder unit with digestible protein, even exceeded the zootechnical norm. When used for haymaking, the grass mass according to these indicators fully met the requirements of DSTU for the production of quality feed.

\section{Conclusions}

For the surface improvement of floodplain meadows of the Carpathian mountain-forest belt with natural grassland, the current factors for increasing their productivity and improving the quality of grass fodder are annual application of $\mathrm{N}_{60} \mathrm{P}_{30} \mathrm{~K}_{60}$, or $15 \mathrm{t} / \mathrm{ha}$ of manure, or $\mathrm{N}_{60} \mathrm{P}_{30} \mathrm{~K}_{60}+$ sowing of a mixture of meadow and thyme use or $\mathrm{P}_{30} \mathrm{~K}_{60}+$ sowing creeping clover for multi-use. In comparison with the variants without fertilizers and with the introduction of $\mathrm{P}_{30} \mathrm{~K}_{60}$, the content of crude protein in the dry mass with hay use increases by $2.3-2.6 \%$, and with multi-mowing - by $4.0-4.1 \%$ and decreases the content of BER, respectively - by $2.0-3.6 \%$, and 2.7-3.1\%.

Under haymaking mode, the highest productivity per 1 ha of fodder units of mountain meadows is provided by sowing a mixture of cereal grasses on the background of $\mathrm{N}_{60} \mathrm{P}_{30} \mathrm{~K}_{60}(2.86-3.34 \mathrm{t})$, and in the case of multi- 
mowing - on sowing of creeping clover on the background of $\mathrm{P}_{30} \mathrm{~K}_{60}(3.04-3.41 \mathrm{t}$ ), which is 12 and $85 \%$ higher, respectively, compared to the options without sowing and 122 and $111 \%$ compared to the option without fertilizer. Application of $\mathrm{N}_{60} \mathrm{P}_{30} \mathrm{~K}_{60}$ increases the productivity of lands by $70-95 \%$, and manure at a dose of $15 \mathrm{t} / \mathrm{ha}$ - by $81-82 \%$.

Multi-use of mountain meadows in comparison with hay in the dry mass increases the content of crude protein by $3.9-4.3 \%$, and protein - by $2.4-3.8 \%$, as well as the content of feed units and metabolic energy, feed security units of digestible protein and digestibility of dry feed in vitro and reduces the content of crude fiber by $2.9-3.2 \%$ and nitrogen-free extractives by $2.5-2.6 \%$.

\section{References}

1. Demydas, H. I., Prorochenko, S. S., \& Svystunova, I. V. (2019). Pozhyvna tsinnist ta enerhoiemnist kormu liutserno-zlakovykh travosumishok zalezhno vid tekhnolohichnykh faktoriv vyroshchuvannia [Nutritional value and energy intensity of feed of alfalfa-grass mixtures depending on technological factors of cultivation]. Crop and soil science, 10(2), 13-21. [In Ukrainian].

2. Katsumata, M., Kobayashi, H., Ashihara, A., \& Ishida A. (2018). Effects of dietary lysine levels and lighting conditions on intramuscular fat accumulation in growing pigs. Animal Science Journal, 89, 988-993.

3. Krys, P. O. (2001). Vplyv mistsevykh mineralnykh dobryv i meliorantiv na vrozhainist siianykh bahatorichnykh trav [Influence of local mineral fertilizers and ameliorants on the yield of sown perennial grasses]. Bulletin of Agricultural Science, 11, 78-80. [In Ukrainian].

4. Olifirovych, V. O. (2012). Produktyvnist ta botanichnyi sklad pryrodnykh luk Peredhiria Karpat zalezhno vid vnesennia azotnykh dobryv ta pidsivu bobovykh trav [Productivity and botanical composition of the natural meadows of the Carpathian foothills depending on the application of nitrogen fertilizers and sowing of legumes]. Scientific reports of the National University of Life and Environmental Sciences of Ukraine, 2(31). Retrieved from http://www.nbuv.gov.ua/e-journals/Nd/2012_2/12ovo.pdf. [In Ukrainian].

5. Petrychenko, V. F. (2012). Aktualni problemy kormovyrobnytstva $v$ Ukraini [Actual problems of feed production in Ukraine]. Agronomist, 3, 196-198. [In Ukrainian].

6. Teberdyev, D. M., \& Rodyonova, A. V. (2015). Efektyvnost udobrenyi na dolholetnem senokose [Efficiency of fertilizers on long-term haymaking]. Feed production, 10, 3-7. [In Russian].

7. Vasileva, V. (2012). Effect of mineral nitrogen fertilization and water-deficiency stress on chemical composition of lucerne (Medicago sativa L.). Grassland Science in Europe, 17, 391-393.

8. Panakhyd, H. la., Kotiash, U. O., Konyk, H. S., \& Yarmoliuk, M. T. (2014). Vplyv dovhotryvaloho vykorystannia luchnykh ahrofitotsenoziv na yikh kormovu produktyvnist [Influence of long-term use of meadow agrophytocenoses on their forage productivity]. Foothill and mountain agriculture and animal husbandry, 56(II), 56-62. [In Ukrainian].

9. Panakhyd, H. la., Konyk, H. S., \& Kotiash, U. O. (2019). Vmist orhanichnykh rechovyn u kormi riznotravno-zlakovoho luchnoho ahrofitotsenozu tryvaloho vykorystannia [The content of organic substances in the feed of grassland meadow agrophytocenosis long-term use]. Foothill and mountain agriculture and animal husbandry, 65, 103-114. [In Ukrainian].

10. Kobyrenko, Yu. O. (2015). Produktyvnist i yakist kormu vidnovlenoho za nulovoho obrobitku gruntu travostoiu [Productivity and quality of forage restored with zero tillage by grass]. Foothill and mountain agriculture and animal husbandry, 57, 99-104. [In Ukrainian].

11. Kovtun, K. P., Veklenko, Yu. A., Yashchuk, V. A., \& Kopaihorodska, H. O. (2018). Produktyvnist vyrodzhenoho starosiianoho luchnoho travostoiu zalezhno vid sposobiv yoho polipshennia $v$ umovakh Lisostepu Pravoberezhnoho [Productivity of degenerate old grass meadow depending on the ways of its improvement in the conditions of the Right-bank Forest Steppe]. Feed and feed production, 85, 82-86. [In Ukrainian].

12. Mashchak, Ya. I., Sloboda, Ya. Ya., Sloboda, O. M., \& Vyhovskyi, I. V. (2012). Ahrobiolohichne obgruntuvannia polipshennia produktyvnosti pryrodnykh kormovykh uhid [Agrobiological justification for improving the productivity of natural forage]. Foothill and mountain agriculture and animal husbandry, 54(1), 40-45. [In Ukrainian].

13. Kotiash, U. O., Buhryn, L. M., Panakhyd, H. Ya., \& Pukalo, D. L. (2019). Osoblyvosti formuvannia riznovikovykh luchnykh travostoiv zalezhno vid poverkhnevoho polipshennia [Features of formation of meadows of different ages, depending on the surface improvement]. Foothill and mountain agriculture and animal husbandry, 66, 117-129. [In Ukrainian]. 787.

14. Gozho, G. (2004). N fertilization of ryegrass in Manitoba. Canadian journal of Animal Science, 84(4),

15. Torell, R., Davison, J., \& Hackett, I. (1984). Improving grass hay qualiti through fertilizer and irrigation management cooperative extension. Reno: University of Nevada. (pp. 44-88).

16. Babych, A. O. (1994). Metodyka provedennia doslidiv z kormovyrobnytstva ta hodivli tvaryn [Methods of conducting experiments on animal feed production and feeding]. Kyiv. [In Ukrainian].

17. Kormy dlia silskohospodarskykh tvaryn. Metody vyznachennia enerhoiemnosti i pozhyvnosti (2017). [Feed for farm animals. Methods for determining energy intensity and nutrition]. DSTU 8066:2015. Kyiv. [In Ukrainian].

18. Dospehov, B. A. (1985). Metodika polevogo opyita (s osnovami statisticheskoy obrabotki rezultatov issledovaniy) [Field experiment methodology (with the basics of statistical processing of research results)]. Moscow: Agropomizdat. [In Russian]. 